ELORE (ISSN 1456-3010), vol. 15 - 1/2008.

Julkaisija: Suomen Kansantietouden Tutkijain Seura ry.

[http://www.elore.fi/arkisto/1_08/mak1_08.pdf]

\title{
KIRJA-ARVIO:
}

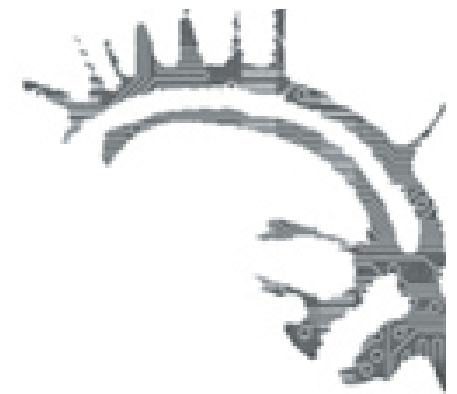

\section{TAITAVA KEITTIÖNAISTEN KANSA}

Knuuttila, Maarit 2007: Kansanomaisen keittämisen taito. Kansatieteellinen

arkisto 50. Helsinki: Suomen Muinaismuistoyhdistys. 336 sivua.

\section{Elina Makkonen}

Ruoka on yksi elämän perusasioista. Se liittyy olennaisesti niin arkeen kuin juhlaankin. Pidämme kuitenkin ruuanlaittamista yleensä tavallisena ja rutiininomaisena toimintana, emmekä kovin tietoisesti pohdi, millaisia perinteitä siihen kaikkineen liittyy tai millaisia taitoja ja varsin monimutkaisiakin keittämisen tekniikoita keittiöissämme käytämme.

Maarit Knuuttila tarkastelee etnologisessa väitöskirjassaan Kansanomaisen keittämisen taito juuri tätä arkista mutta merkityksellistä naisten hallitsemaa kenttää. Tutkimuksessa keskitytään keittämistaidon ominaisluonteen ja sen piirteiden pohtimiseen ja esilletuomiseen mutta pyritään myös löytämään linkkejä menneisyyden ja nykyisyyden välillä. Keittämisen taitoa tarkastellaan noin 150 vuoden aikajaksolla. Painotus on 1900-luvun alkupuolella, jolloin lähes kaikki ruokatarvikkeet kasvatettiin itse ja suurin osa ruuasta tehtiin kotona.

\section{KEITTÄMISEN TAITOA JÄLJITTÄMÄSSÄ}

Keittämiseen liittyvää yksilöllistä ja kollektiivista tietoa tutkija jäljittää tulkitsemalla ja keskusteluttamalla erilaisia lähdeaineistoja: suomalaisia keittokirjoja, kirjoitettuja lapsuuden ruokamuistoja ja suullisia keittämistarinoita. Keittokirjat ovat kulttuuri- ja sosiaalihistoriallisia lähteitä ja kulttuurisia tekstejä, joihin kirjoitetaan, tutkijaa lainatakseni, erilaisia yhteiskunnallisia ideologioita ja näitä tukevia artikulaatioita. Keittokirjoista voidaan tutkia esimerkiksi sitä, mitkä kulloinkin on koettu kunnollisiksi ja sopiviksi arkikeittämisen ja ruokailemisen tavoiksi. Silti on huomattava - ja näin Knuuttila tekeekin - etteivät keittokirjat itsessään kerro arkikokemuksesta eli siitä, miten ohjeita ruuanlaitossa on eri aikoina käytetty. 


\section{TAITAVA KEITTIÖNAISTEN KANSA}

"Lapsuuden ruokamuistoja" -keruu toteutettiin 1990-luvun lopussa Pirkkalehdessä toisen tutkijan tutkimusta varten. Maarit Knuuttila on valinnut vastauksista omaksi tutkimusaineistokseen 224 kirjoittajan tekstit, jotka ajoittuvat 1920- ja 1940luvuille. Hänen itsensä kokoama haastatteluaineisto puolestaan koostuu kymmenestä elämäkerrallisesta keittämistarinasta. Haastateltavat ovat eri-ikäisiä keskisuomalaisia naisia, ja he kuuluvat kahteen eri sukuun.

Tutkimus jakaantuu viiteen osaan. Johdannon eli teoreettisten lähtökohtien, aineistojen ja niiden analyysitapojen sekä yhteenvedon väliin mahtuu kolme aineistolukua. Niistä ensimmäisessä tarkastellaan ruokatarvikkeiden ja luonnonympäristön yhteyttä sekä keittävän ihmisen sitoutumista maahan, maaperään ja luontoon. Tulkinnat pohjautuvat "Lapsuuden ruokamuistoja" -aineistoon. Tutkija on kuvannut, mitä luonnosta kerätyistä, itse kasvatetuista ja säilötyistä ruoka-aineista on keitetty, mutta on samalla pyrkinyt tavoittamaan ihmisen maasuhteesta myös yhteisöllisiä arvostuksia ja mentaliteettikerroksia.

Seuraavaksi analysoidaan ja keskustelutetaan keittokirjoja ja lapsuuden ruokamuistoja. Knuuttila tarkastelee muun muassa sitä, miten tieteellisperäiset käsitykset keittämisestä ovat syntyneet ja miten ne ovat vaikuttaneet keittämisen liikkeisiin. Hän osoittaa, etteivät tieteellisen keittämisen vaateet ja kansanomaisen keittämisen systematiikka aina kohdanneet. Esille tulee myös keittokysymys, jonka puitteissa keittäminen pyrittiin kytkemään ideaan kodista ja kotikulttuurista, johon artikuloitiin säntillinen kodinhoito ja järkiperäistetty kotitalouden toimien järjestäminen. Kolmannessa aineistoluvussa keskitytään haastatteluihin ja keruuaineistoon pohjautuen keittiönaisten kansaan ja keittämisperinteisiin. Siinä tarkastellaan keittäviä äitejä ja heidän keittämistapojaan mutta myös keittäjäksi kasvamista.

Knuuttila on hyödyntänyt paljon monipuolista tutkimusaineistoaan, ja siten kentän ääni kuuluu tutkimuksessa. Keittämisen taitoa havainnollistavat myös Keski-Suomen muistiarkistosta valikoidut valokuvat. Itse ihmettelin, miksei kuviin ole liitetty minkäänlaisia tietoja kuvausajankohdasta. Onkohan tämä tietoinen ratkaisu, eli onko tutkimuksessa haluttu rakentaa menneisyyteen sijoittuvaa mutta kuitenkin tietyllä tavalla ajatonta tulkintaa keittämisperinteistä?

\section{KEITTÄMINEN NAISTEN ARKITAITONA}

Tutkimuksen keskiössä on kodin piirissä tapahtuva keittäminen. Maarit Knuuttila ei käytä käsitettä ruuanlaittaminen vaan tavoittelee keittämisen käsitteellä nimenomaan naisten harjoittamaa ruuanvalmistuksen aktia kokonaisvaltaisemmin. Keittämistä tarkastellaan laajasti praktisena toimena ja merkityksiä heijastavana kulttuurisena toimintana. Keittäminen ei ole tutkijan mukaan vain mekaanista suorittamista vaan kulttuuriseksi tietämiseksi ja teknisiksi sovelluksiksi luonnehdittavaa taitoa, jossa ruokaa tuotetaan elämisen erilaisiin tilanteisiin ja tarpeisiin. Arkikeittäminen näyttäytyy tutkimuksessa monimutkaisten taitojen yhdistelmänä, joka vaatii muistamista, suunnittelua, järjestelemistä, mittaamista, laskemista, kekseliäisyyttä ja luovuutta. 


\section{ELINA MAKKONEN}

Tutkija nostaa tarkastelunsa kohteeksi keittiönaisten kansan (ranskankielinen käsite le peuple féminin des cuisines on lainattu Lucy Giardilta). Keittäminen on ollut, ja on edelleenkin, pääasiassa naisten hallitsema arkitaito. Keittämällä nainen, yleensä äiti, paitsi luo elämälle välttämätöntä ruokaa ja ravintoa niin samalla välittää yhteisössä vallitsevia perinteitä. Keittämisperinteet ovat siirtyneet äidiltä tyttärelle tai anopilta miniälle. Keittämistä ei varsinaisesti ole opetettu, vaan taitoon on kasvettu äidin keittämisen liikkeitä tarkastelemalla ja keittämiseen osallistumalla. Kaiken kaikkiaan keittämiseen liittyvän hiljaisen tiedon omaksuminen, keittämistaidon oppiminen samoin kuin ruokakulttuuriin kasvaminen ja sen sisäisen merkitysjärjestelmän omaksuminen on laaja-alainen ja monitahoinen enkulturaatioprosessi. Nykyisin keittämistä opitaan kodin lisäksi myös mitä enenevässä määrin muun muassa lehdistä, television ruokaohjelmista ja keittokirjoista.

\section{IHANNOITU KEITTÄJÄNAINEN JA KEITTÄMISEN KEHOLLISUUS}

Käytetyistä muisteluaineistoista nousee esille maan, tulen, kodin ja keittävän äidin yhteydestä syntynyt nostalgisoidun keittäjänaisen ihanne, jonka rinnalle tutkija on nostanut myös reaalisen keittäjänaisen. Tässä yhteydessä Maarit Knuuttila toteaa oivaltavasti sen seikan, että menneisyydestä on ihannoituun keittäjänaiseen liitetty nykyisyydestä katsottuna parhaana pidettyjä ulottuvuuksia. Näitä ovat muiden muassa neuvokkuus, luovuus, kekseliäisyys, voimakkuus ja kyvykkyys.

Vaikka menneisyyttä pidetään keittämisen ideaalina, ei kaikkia piirteitä menneisyydestä suinkaan sisällytetä nostalgisoidun keittämisen kuvaan. Esimerkiksi niukkuus, köyhyys, nälkä ja puute eivät tule esille, vaikka ne kuuluvatkin olennaisesti suomalaiseen ruokakulttuuriin. Nostalgisoidun keittäjänaisen idea sitoo Knuuttilan mukaan myös nykynaisia perinteisiinsä. Vaikka kansanomaiset taidot kiinnittyvät traditioihin, ne myös uusiutuvat ja jättävät tilaa luovuudelle. Keittävä nainen joutuu uusissa tilanteissa arvioimaan uudelleen perimiään tapoja ja etsimään arkisiin ongelmiin uusia ratkaisumalleja.

Keittämiseen liittyy vahvasti kehollisuus, jonka Maarit Knuuttila määrittelee oman tutkimuksensa kontekstissa mutkikkaaksi aistilliseksi tietämiseksi ja muistamiseksi. Kehollisuus tulee esille esimerkiksi mittaamisessa ja taikinan teossa. Mitatessaan jauhoja taikinaan leipoja käyttää tarkkojen mittojen lisäksi omien käsiensä mittoja, kuten kourallisia. Pulla- tai leipätaikinan teko-ohjeessa voidaan kuitenkin yleensä antaa vain summittainen jauhomäärä, mutta sopivan jauhomäärän tietää - tai oikeammin tuntee - käsillään. Kehon tekniikoiden suorittajana on yksilö, keittävä nainen, mutta kuitenkin käytetyt tekniikat ovat kollektiivisesti muotoutuneita ja perustuvat perinteille. Rutiinin, esimerkiksi pullataikinan teon taustalla on siis kulttuurinen käytäntö. 


\section{TAITAVA KEITTIÖNAISTEN KANSA}

\section{KEITTÄVÄ TUTKIJA TARKASTELEE RUOKAESINEITÄ}

Oman sävynsä Maarit Knuuttilan tutkimukseen tuo tutkijan kokemuksellisuus, hänen "olemisensa paikallisessa tiedossa". Knuuttila tarkastelee keittämistä ja lukee aineistojaan paitsi etnologina myös kokkina, keittiömestarina ja keittävänä äitinä. Hän siis hallitsee itsekin ne taidot, joita tutkii, ja on pystynyt käyttämään hyväkseen kokemuksiaan siitä, miten erilaisilla keittämisen kentillä toimitaan ja millaiset merkitysjärjestelmät niillä vallitsevat.

Knuuttila on kyennyt oman tietämyksensä kautta jäljittämään sellaisiakin keittämisen merkityksiä, joita ei voi verbalisoida. Hän on tavallaan kokenut oman kehonsa kautta keittävät liikkeet keittokirjoja tai muisteluaineistoja lukiessaan ja keittäjänaisia haastatellessaan. Tutkimusta lukiessani seurasin itsekin mielessäni keittävän kehon liikkeitä niissä kohdissa, joissa kuvattiin minulle tuttuja keittämisen tapoja.

Kentän tutkimisessa voi myös piillä sitoutumisen ansa, kuten Maarit Knuuttila on oivaltanut. Miten tutkia aihetta, joka on itselle todella tuttu ja läheinen? Tutkijan ammattitaitoon kuuluu kyky ottaa etäisyyttä silloinkin, kun aihe on tuttu. Se ei välttämättä ole helppoa, mutta mielestäni Maarit Knuuttila on onnistunut varsin hyvin tässä tehtävässä.

Tutkimusta lukiessani ihmettelin käsitteen ruokaesine käyttöä. Vaikka Knuuttila perustelee hyvin käsitteen käytön, niin en voinut olla ajattelematta, että hän jossain määrin puolustaa omaa tutkimustaan etnologian kentällä, jossa on vanhastaan tutkittu nimenomaan materiaalista kulttuuria ja ympäristöä. Ajatus ruuasta hetkellisenä esineenä on sinällään kiinnostava. Ruoka säilyy mielikuvina eikä artefakteina, kuten vaikkapa käsityö tai vanha huonekalu, joiden tekotapoja voidaan tutkia hyvin ilman kerronnallista tulkintaa. Keittäminen ja sen muodot taas säilyvät kerronnallisesti ja kehollisesti puhunnoissa, rutiineissa, teknisluontoisissa malleissa ja teksteinä keittokirjoissa. Etnologiassa onkin aiemmin tarkasteltu ruokalajeja ja luokkia eikä keittämistä ja keittävää naista. Siksikin Knuuttilan tutkimus on tärkeä.

\section{NAISTAIDON ANALYYSISTA MIESKEITTÄMISEEN}

Vaikka Maarit Knuuttilan väitöskirja pureutuu sukupuolittuneeseen keittämiseen ja siten kuuluu selkeästi naistutkimuksen alaan, tämä näkökulma ei tule korostuneesti esille. Tutkija ei esimerkiksi tutkimuksen johdannossa tuo paljonkaan esille naistutkimuksen piirissä käytyjä keskusteluja, joita olisi taatusti voinut hyödyntää enemmän. On toki muistettava, että Knuuttila on halunnut tarkastella keittämisen kenttää arkisen taidon näkökulmasta ja tämä on rajannut sitä, millaisten aiempien tutkimusten ja näkökulmien kanssa hän on keskustellut.

Nostaessaan esille naisten keittämisen taidon Maarit Knuuttila tekee kunniaa keittäville naisille. Uskon, että käytetyistä aineistoista olisi toisenlaisella lukutavalla ja kysymyksenasettelulla voinut tuottaa erilaisen tulkinnan, jolloin naisen asemaa keittäjänä olisi voinut tarkastella korostetummin sukupuolittuneen työnjaon näkökulmasta 


\section{ELINA MAKKONEN}

jonkinlaisena nyrkin ja hellan väliin paikantuvana pakkona, tavallisena ja jopa tylsänä arjen toimintona.

Tutkimuksensa lopussa Maarit Knuuttila tuo esille mahdollisen jatkotutkimuksen aiheen, keittävien miesten maailman. Avatessaan kysymystä miesten keittotaidosta, hän pohtii, ovatko äitien keittämisen tavat edelleen se perusta, jolle myös miesten kotikeittäminen perustuu. Keittämisen perinteet ovat kuitenkin tiettyihin arkisiin taitoihin sisään rakentuneita kehollisia, kollektiivisia tekniikoita, jotka määrittävät ammattikeittämisen kentältä tulevien tekniikoiden ohella myös koteihin paikantuvaa mieskeittämistä.

Filosofian lisensiaatti Elina Makkonen tekee Joensuun yliopistossa perinteentutkimuksen väitöskirjaa muistitietotutkimuksesta. 